\title{
Impact of globalisation on circular economy and sustainable development
}

\author{
Iveta Máliková ${ }^{1 *}$ \\ ${ }^{1}$ Faculty of Mass Media Communication UCM, Námestie J. Herdu 2, Trnava, Slovakia
}

\begin{abstract}
Currently, the issues related to the global threats of the environment represent a special, increasingly more significant category of global issues. The main cause of the constantly changing conditions of the environment is the economic growth itself as it is closely connected to the growth of population, satisfaction of the man's needs and a consequent increase in consumption. With the increase in consumption, there is an increase in the use of natural resources which we perceive as a usable resource that results in the transformation of raw materials into materials being used in the production of consumer goods. The energy used in the production, together with the reusable resources, is being later returned to the economic cycle in the form of waste. However, the way we currently use resources is not sustainable. To ensure sustainable development in the Slovak Republic, as well as in the whole European Union, we need to employ resources in a more inteligent, sustainable way. It is evident that the linear model of economic growth, that we relied on in the past, does not fullfill the needs of present, modern societies in the globalized world. The transition to a circular economy seems to be an appropriate system that can provide environmentally- and economically- sustainable use of available resources, and, thereby, being able to support the main objective within the Strategy for Smart, Sustainable and Inclusive Growth - Europe 2020.
\end{abstract}

\section{Global Environmental Problems}

Over the past decades, many changes have taken place on our planet, such deepening economic disparities, global warming, reducing the ecosystem's production capacity, deforestation, increasing pollution or the consumption of non-renewable resources [1]. Significant degradation can be observed on the natural resources upon which the world economy depends. However, the scarcity of natural resources may become a more significant limit for the economic growth than the lack of the financial capital or industrial infrastructure in the near future. The ecosystem degradation takes several forms, such as: extinction or threat of extinction of many plants or animal species, deforestation, extinction of fish in the oceans, reduction of a drinking water supply or degradation of soil or mineral resources. For a long time, world experts have intensively pointed out the negative consequences of economic human activities, which have an irreversible impact on the environment. While in the past there was a pressure on the environment concentrated rather on small areas [2].

\footnotetext{
*Corresponding author: iveta.malikova@ucm.sk
} 
Nowadays this situation has changed. As a result of an increasing human population in the world and economic development, is an unsustainable use of natural resources which causes a serious global environmental damage for the nature [3].

The way we use resources is not sustainable any longer. We consume and extract far more raw materials than our planet can provide for us in the long term. In addition, the concentration of key raw materials leads to the dependency on industries and population on imports and increasingly exposes people to bear consequences of high prices, market fluctuations and the political situation in supplying countries. For this reason, we can say that the global struggle for resources is steadily growing. Consumers' life style associated with extended consumption of products which is constantly increasing. This reality can be explained by the fact that marketing experts always look for new trends and impulses that, despite consumers' reluctance to use traditional advertising forms, still influence their purchases and consumption preferences [4] "Needs and values of citizens are placed into the environment of overproduction (more products are produced than are needed by the total social need; businesses make higher profits) and over-consumption (more products are consumed than are needed by the total social and individual needs and the purchasing power of the population; non-renewable resources are consumed and wasted) '[5].

Consumers are buying more and more products that will expire after a time or loose their value for money, eventually they do not manage to consume them in time and they will end up as a waste. Moreover, the mountains of waste are left behind as an unpleasant gift for our future generations. Yet, not all waste is really waste. More than half of this waste can be used as a secondary raw material. This fact is also recognized by companies that, in an effort to protect the environment, apply the concept of a circular econom. The concept of the circular economy is an economic system aimed at eliminating waste and the continual use of resources. Circular systems employ reuse, sharing, repair and recycling. This implies that all products and materials will be reconnected to their cycle after use, where they will subsequently become sources for the production of new products and services.

\section{The Circular Economy}

Unlike the linear economic model, the 'circular economy' aims to maintain as long as possible the value of materials and energy used to produce products, minimize waste and make use of resources. A transition to the circular economy should not only promote competitiveness, but also contribute to the economic growth, job creation and environmental protection. At the same time, it can offer more durable and innovative products in order to save consumers'money and improve the quality of their life.

As already mentioned, the 'circular economy' aims to preserve the value of materials and energy used to produce products in the chain of values at the optimum time, while minimizing waste and use of resources. By preventing a loss of material flow, it creates economic opportunities and competitive advantages on a sustainable basis. Of course, a successful transition to the circular economy requires action at all stages: from raw materials extraction through materials and products design, production, distribution and consumption of goods, repair, reuse and recovery systems to waste management and recycling.

In this process, it is necessary to perceive primarily the initial state of products, which includes reducing use of primary raw materials, an energy efficiency of production, as well as a waste reduction generated during the production stage, addressing the possibility of future reuse of the product and its parts (materials). Last but not least, the interest of manufacturers should be focused on extending a lifespan of the product. All these points must be addressed not only during production, but also during the design of the product itself. 
Investment and innovation will be key to enable the transition from a linear economy to a circular economy [6].

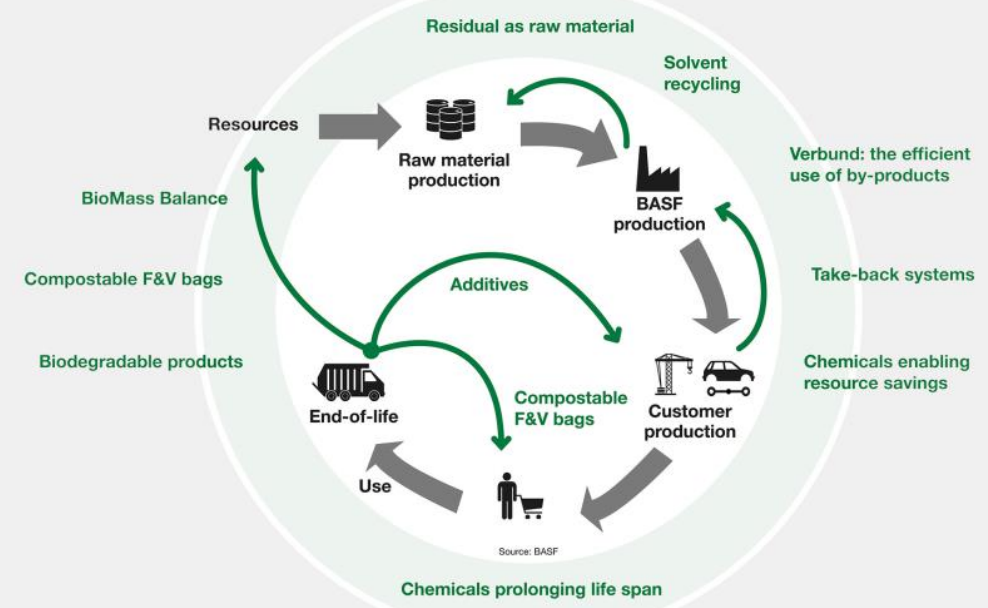

Fig. 1. Circular Economy - the graph

As part of the transition to the circular economy, the European Commission adopted an ambitious circular economy regulation package in 2015. The focus of this package is on the EU Circular Economy Action Plan, with measures covering the whole life cycle of a product: from design, resources, production and consumption to a waste management and the secondary raw materials market. Compared to the linear model, the circular economy separates economic growth from its need to extract new and rare materials. Actually, this is ensured by the implementation of material savings, re-use, change of eco-design of products and development of new products and services with reduced material intensity, or reuse in the circulation cycle.

Environmental threats in the form of waste accumulation, mismanagement and wastage are also a major problem, for the natural resources such water, material resources, air pollution and pollution of the nature in general. For this reason, the package includes waste legislative proposals containing long-term targets for reducing landfill volumes and increasing the rate of recycling and re-use. The package also includes the European Plastics Strategy, where there is fully approved and taken into account reuse, repair, recycling and the development of the more sustainable materials. The immediate implementation of the waste legislative package is particularly important for new investments in larger scale and better recycling policies across the EU.

In conjunction with the goals of the 2030 Sustainable Development Agenda and its principles, the transition to the circular economy will mainly contribute to the 12th objective - Ensure Sustainable Consumption and Production Schemes, which defines the needs of countries' economies to eliminate existing problems with the availability of natural resources. meeting the Europe 2020 headline target of reducing negative environmental impacts as well as enhancing the security of raw materials supply, enhancing competitiveness and innovation, and hence an increasing growth and job creation.

When the circular economy is put into practice, changes in production and consequently in consumption are essential. When creating them, emphasis must be on the circulation (repair, durability, recyclability) of products. At the same time, the sectors of economy 
producing and consuming materials and products, as well as households, must reduce the amount of waste they generate. Prevention is closely linked with the improvement of the production methods and influencing consumers in their search for environmentally friendly products and reducing packaging. Reducing the amount of generated waste is a high priority within the waste hierarchy defined in the Waste Act, which sets out a priority order, starting with the prevention, preparation for re-use, recycling and energy recovery to safe disposal, such as landfilling. In the long run, this can contribute to the conservation of primary raw material resources and thus to a higher self-sufficiency of the selected raw materials used in production processes.

Use of a raw material base such as non-renewable energy sources, materials and products based on minerals or plastics is one of the prerequisites for implementing the principles of the circular economy and provide the possibility to reduce the country's energy and raw materials dependence. Ideally, the resources of these raw materials are recycled back into the system or are handled in such a way that as little waste is generated as possible. In Slovakia, a total of $8,717,776.94$ tonnes of waste (excluding municipal waste) was produced in 2016, while only less than $46 \%$ of this waste was recovered. Of the other 1,953,478.2 tonnes of municipal waste from towns and municipalities, only $11.8 \%$ was recovered. Of the given amount of generated waste, a large amount is still disposed without landfill, for the waste outside municipal it is $28.6 \%$ of the total amount of generated waste and for municipal waste up to $66 \%$ of its total amount.

\section{Sustainable Development}

"In the context of a constant population growth, reducing non-renewable resources and environmental degradation, there is an increasing pressure to rationalize economic processes towards sustainable development," [7] which means that, manufacturing companies should use resources more wisely within sustainable development, they should design products to be reusable and recyclable, and set ambitious targets of waste reduction and recycling.

The European Parliament has formulated sustainable development as an efficient tool for improving the standard of living and well-being of people within the limits of our ecosystem capacity while preserving the nature and biodiversity for present and future generations. It is similarly perceived by following authors: Šálková, Regnerová and Hes, according to whom "it represents a balance of economic, social and ecological aspects of life of a prosperous society that will use its resources sparingly, while sustainability is not only a target state, tackling the most pressing and topical issues "[8] in order to improve the quality of the environment, to protect human health, to wisely use natural resources, minimize waste and enforce measures not only at regional level but also internationally.

The transition to the circular economy can boost competitiveness and innovation by stimulating new business models and technologies, while facilitating social innovations. This will make the European economy more sustainable and competitive in a long term. Of course, all business entities must accept ongoing changes and adapt themselves to these economic conditions. Those who cannot adapt, they do not have any chance to succeed in the tough competitive enviroment in this market. It might result to a disappearance of business entities that cannot assimilate with these new conditions. For this reason, each business must set its own successful story and be adaptable to the constant changes in the economy [9]. Above all, they need to introduce new methods, tools and techniques, set ambitious goals, rely on sustainable performances, pursue a comprehensive set of criteria, strive for strategic innovations, create a dynamic and flexible organizational governance structure, and improve key competencies [10]. 
Also, the state policy in the transition to the circular economy and sustainable development efforts has an important role to play. In order to achieve a competitive circular economy in Europe, in addition to adopting and implementing the individual EC actions and strategies, it pursues a waste management policy, addressing the entire product life cycle, taking into account the situation in all Member States. This includes various measures in the fields of smart product design, re-use of products and repair, recycling, a sustainable consumption, a waste management policy, recycling levels, a wise use of raw materials, stronger markets for secondary raw materials, as well as targeted sectoral measures. However, an effective precondition for a successful transformation of the current unsustainable system based on the effective cooperation of all stakeholders, research, development, industry and government-supported financial and legislative services, including customers expected to change their behavior.

\section{Practise}

The transition of companies to the circular economy and the changing patterns of resources use over the past decades are evidences that progress in resource efficiency, which is completely realistic. In the last 20 years, recycling has become a commonplace for all businesses and households across the EU, which has significant impact on the industries such as paper, glass and mining. The legislation at the EU level has also contributed to reducing carbon emissions: The EU greenhouse gas emissions have fallen by more than $10 \%$ since 1990, while the European economies have increased by $40 \%$ over the same period.

To maximize economic growth while relieving pressure on the resources base, there are five basic rules that must be followed:

save: take advantage of the existing opportunities to save resources wherever possible - some EU economies are 16 times more efficient than others;

- recycle: increase recycling of materials and reuse elements in products (mobile phones, clothing);

- replace: replace primary resources inputs with their alternatives that are more efficient and have lower environmental impacts throughout their life cycle (for example by phasing out mercury);

- reduce: dematerialize the way people meet their needs through new business models or low-input goods and services, such as reducing vehicle weight or prioritizing legally downloading music and entertainment from the Internet rather than buying solid items such as DVD;

- $\quad$ establish the value: policy makers must find ways to set the right value of the natural resources in their decisions, which can help to improve the management of our natural resources base. By learning how to value and assign the right price to the ecosystem services and natural resources, we can help to reduce the pressure on the environment.

\section{Conclusion}

The environmental protection, resource efficiency and waste management are among the challenges that need to be addressed globally. The way we currently use resources to produce new products is not sustainable. We are already consuming and extracting more raw materials than our planet is able to provide in the long term. The same can be applied to waste. With increasing consumption, waste dumps are also increasing, which has a negative impact on the environment and human health. The public is interested in creating ecological balance and renewing harmony between a man and nature [11]. A solution to this problem may be in 
the transition to the circular economy, which will contribute to reduce the environmental and health problems caused by our current linear economy. In practice, however, this will require major changes in production and consumption systems, far beyond a resource efficiency and waste recycling. Practical examples illustrate that the transition to the circular economy is delivering positive results.

This contribution was made within the VEGA project no. 1/0078/18 entitled "Aspects of marketing communication in management processes of the circular economy."

\section{References}

1. E. Stonkute, J. Vveinhardt, W. Sroka, Training the CSR Sensitive Mind-Set: The Integration of CSR into the Training of Business Administration Professionals. Sustainability 10, 3, 754 (2018)

2. M. Poliak, A. Krizanova, S. Semanova, L. Stefanikova, The impact of procurement method of the transport services to the financial requirement of performance contracting entity. Transport problems 8, 4, 67-76 (2013)

3. Z. Musová, H. Musa, Z. Huliaková, Innovative Approaches in a Socially Responsible Marketing in a Global Environment. Globalization and Its Socio-Economic Consequences. 1467-1470. (2016)

4. M. Olšiaková, M. Šupín, A. Dovčíková, M. Triznová, Murketing and its Application in Practice. Globalization and Its Socio-Economic Consequences. 549.(2015)

5. A. Hes, I. Hesová, Aspects of Global Communication in Post Modern Society. Globalization and Its Socio-Economic Consequences. 636 - 645. (2016)

6. V. Jurišová, CSR Activities in Environmental Area - Global Trends and Best Practices. Globalization and Its Socio-Economic Consequences. 828-835. (2017)

7. L. Szkuráková, J. Alchus, J. Bednárik, The Global Crisis and its Impact on the Economy of the Comanies in Slovakia. Globalization and Its Socio-Economic Consequences. 737 - 742. (2015)

8. D. Šálková, M. Regnerová, A. Hes, Global Extend of Food Waste. Globalization and Its Socio-Economic Consequences. 755 - 763. (2015)

9. P. Richnák, Globalization and its Impact on the Present Concepts in Company Management. Globalization and Its Socio-Economic Consequences. 608 (2015)

10. A. Jacková, Modern Business Management and Management Accounting. Globalization and Its Socio-Economic Consequences. 247 - 253. (2015)

11. A. Zaušková, L. Grib, Impact of Globalization on Slovak Business in Marketing Promotion of Eco-innovations. Globalization and Its Socio-Consequences. 2466. (2016)

12. M. Nadanyiova, E. Kicova, M. Rypakova, Green marketing and its exploitation in Slovak companies. In 4th World Conference on Business, Economics and Management (WCBEM), Ephesus, Turkey, 219-226, (2015)

13. Globálne problémy a podnikanie. [online]. Available at: http://www.ekologika.sk/globalne-problemy-a-podnikanie.html (2019)

14. Obehové hospodárstvo budúcnost' rozvoja Slovenska [Online]. Available at: https://www.enviroportal.sk/uploads/report/9202.pdf

15. Správa o stave životného prostredia Slovenskej republiky v roku 2016 [Online]. Available at: https://www.enviroportal.sk/uploads/report/7626.pdf 